\title{
Respon Pertumbuhan dan Produksi Rumput Benggala (Panicum maximum) Terhadap Aplikasi FMA (Fungi micoriza arbuscula) dengan Beberapa Jenis Pupuk Kandang
}

\author{
Oktovianus R. Nahak T. B ${ }^{\mathrm{a}}$, Gaudensius Haki ${ }^{\mathrm{b}}$, Marianus Nufa Maunnaijuf \\ ${ }^{a}$ Fakultas Pertanian, Universitas Timor, Kefamenanu, TTU - NTT, 85613, Indonesia. \\ ${ }^{b}$ Fakultas Pertanian, Universitas Timor, Kefamenanu, TTU - NTT, 85613, Indonesia. \\ ${ }^{c}$ Fakultas Pertanian, Universitas Timor, Kefamenanu, TTU - NTT, 85613, Indonesia.
}

\section{Article Info}

Article history:

Received 14 Juni 2015

Received in revised form 12 Juli 2015

Accepted 5 Oktober 2015

Keywords:

Panicum maximum

Fungi mikoriza arbuscula

Pupuk kandang

\section{Abstrak}

Penelitian ini bertujuan mengetahui sejauh mana nilai pertumbuhan (tinggi tanaman, diameter batang dan lebar daun) dan produksi (berat segar tajuk, berat kering tajuk dan kadar air) rumput Benggala (Panicum maximum) yang diberi aplikasi FMA (Fungi micoriza arbuscula) dengan variasi beberapa jenis pupuk kandang. Pelaksanaan penelitian dilakukan pada lahan milik masyarakat dikelurahan benpasi, kecamatan kota kefamenanu, kabupaten TTU. Adapun rancangan yang digunakan dalam penelitian ini adalah rancangan acak kelompok yang terdiri dari 4 perlakuan dan 4 ulangan. Perlakuan yang diuji dalam peneltian ini terdiri dari : Ro: Tanpa FMA dan pupuk kandang; 2) R : FMA $30 \mathrm{~g}$ + feses sapi $500 \mathrm{~g}$ per lubang tanam; 3) R2: FMA $30 \mathrm{~g}+$ feses ayam $500 \mathrm{~g}$ per lubang tanam; 4) R3: FMA $30 \mathrm{~g}$ + feses kambing $500 \mathrm{~g}$ per lubang tanam. Hasil penelitian menunjukkan bahwa terdapat perbedaan kecepatan tumbuh (tinggi tanaman, lebar daun, diameter batang dan jumlah anakan) pada tanaman rumput Benggala pada masa produksi I dan II, sedangkan secara komulatif dari hasil penelitian nampak bahwa pemberian Mikoriza $30 \mathrm{~g}+$ feces sapi $500 \mathrm{~g}$ memberikan kontribusi terbaik terhadap variabel tinggi tanaman $(57,72 \mathrm{~cm} /$ bedeng/minggu) dan berat kering tajuk $(563,44 \mathrm{gr} / \mathrm{bedeng})$ sedangkan pada perlakuan Mikoriza $30 \mathrm{~g}$ + ayam $500 \mathrm{~g}$ memberikan kontribusi terbaik terhadap variabel lebar daun $(2,34 \mathrm{~cm} / \mathrm{bedeng} / \mathrm{minggu})$, diameter batang $(1.43$ $\mathrm{cm} /$ bedeng/minggu), jumlah anakan (13.86 bedeng/minggu), berat segar tajuk (2752,10 gr/bedeng) dan kadar air daun (80,63\%). (02016 dipubikasikan oleh JAS

\section{Pendahuluan}

Budidaya hijauan pakan ternak unggulan memiliki peranan penting dalam upaya mencukupi kebutuhan pakan ternak baik secara kualitas maupun kuantitas sehingga produktivitas ternak dapat dicapai secara maksimal. Rumput merupakan salah satu hijauan yang dibutuhkan bagi ternak ruminansia sebagai pakan dasar dimana memiliki manfaat untuk memenuhi kebutuhan hidup, untuk produksi dan reproduksi ternak. Sebagai pakan dasar rumput memiliki peranan penting menggingat kebutuhan rumput sebagai pakan ternak dibutuhkan dalam jumlah besar porsinya dalam penyusunan ransum ruminansia.

Budidaya rumput unggulan saat ini banyak mendapat perhatian dalam kalangan peneliti dan masyarakat peternak hal ini dikarenakan sampai saat ini ketersediaan rumput sebagai pakan ternak menjadi permasalahan dari prospektif kuantitas maupun kualitas terutama pada daerah tropis di pulau Timor setiap tahunnya. Penerapan aplikasi teknologi merupakan salah satu upaya yang perlu dilakukan dalam rangka mencapai produksi hijauan sehingga diharapkan permasalah ketersediaan hijauan dapat tercukupi setiap tahun.

Rumput Benggala (Panicum maximum) merupakan salah satu rumput unggulan yang telah banyak dibudidayakan di kalangan petani peternak. Di Indonesia rumput ini dikenal dengan rumput Benggala, di Inggris dikenal dengan nama Guinea grass dan di Jawa dikenal dengan nama Suket Londo. Rumput ini didatangkan dari Simbabwe termasuk tipe sedang dengan tinggi tanamam 1,5-2,5 m. Rumput ini merupakan tanaman tahunan yang tidak membentuk hamparan tetapi membentuk rumpun. Tekstur daun halus lebih lebar dan panjang dengan sembilan tulang daun tengah yang lebih nyata, tepi daun kasar bunganya membentuk mayang dan mudah berbiji (Skerman dan Riveros, 1990). Introduksi rumput Benggala ke Indonesia dilakukan dalam rangka menyediakan bibit rumput ungulan untuk kebutuhan penyediaan pakan ternak pada wilayah tropis.

Tanah merupakan media tumbuh bagi hijauan yang sangat potensial bagi pengembangan tanaman rumput. Tanah memegang peranan penting mengingat ketersediaan hara maupun mikroorganisme tanah memiliki peranan penting terhadap pertumbuhan tanaman. FMA (Fungi micoriza arbuscula) merupakan salah satu produk pupuk hayati yang bekerja pada sistem perakaran dan terbentuk sebagai manifestasi adanya simbiosis mutualistis antara fungi (myces) dan perakaran (rhiza) dari tumbuhan tingkat tinggi. Rohyadi (1987) menyatakan bahwa micoriza merupakan fenomena jamur menginfeksi dan mengkoloni akar tanpa menimbulkan nekrosis sebagaimana biasa terjadi pada infeksi jamur patogen dan mendapatkan pasokan nutrisi secara teratur dari tanaman. Menururt Owusu-Benoal dan Wild (1980), adanya assosiasi antara cendawan pembentuk micoriza dengan akar tanaman inang memberikan keuntungan bagi tanaman inang dimana dapat memperluas permukaan bidang penyerapan akar atau meningkatkan volume tanah yang dieksplorasi. Hatch (1973) menyatakan bahwa akar yang bermicoriza dapat meningkatkan kapasitas pengambilan unsur hara, karena waktu hidup akar terinfeksi diperpanjang dan derajat percabangan serta diameter diperbesar sehingga luas permukaan absorpsi diperluas. Selanjutnya Setiadi (1990) menyatakan bahwa tanaman yang bermicoriza akan tumbuh lebih baik dari tanaman tanpa micoriza, karena micoriza secara efektif dapat meningkatkan penyerapan unsur hara makro. Selain itu akar yang bermicoriza dapat menyerap unsur hara dalam bentuk terikat dan tersedia bagi tanaman. Dan disamping itu selain membentuk hifa internal, micoriza membentuk hifa eksternal yang berfungsi menyerap phosphor dari dalam tanah. Phosphor yang telah diserap oleh hifa eksternal akan segera ditransfer ke tanaman induk.

Upaya meningkatkan nilai kesuburan tanah akan semakin baik tentunya bila tanah mampu menyediakan unsur hara makro. Menurut Santoso (1994), pemupukan merupakan syarat mutlak dalam membudidaakan suatu tanaman, pemupukan bertujuan untuk menggantikan unsur hara yang hilang karena proses pencucian dan pengangkutan bersama limbah pertanian.

Ketersediaan unsur hara pada tanah dapat dilakukan melalui strategi pemupukan yang aman dan ramah lingkungan. Menurut Novizan (2004), pupuk kandang adalah pupuk yang berasal dari kotoran-kotoran hewan yang bercampur dengan sisa makanan dan urin yang di dalamnya mengandung unsur hara N, P dan K yang dapat digunakan untuk kesuburan tanah.

Jenis pupuk kandang yang banyak tersedia di lingkungan masyarakat antara lain pupuk kandang sapi, pupuk kandang ayam dan pupuk kandang kambing, dimana ketiganya memiliki bentuk fisik dan kandungan yang berbeda. Pemberian pupuk yang benar akan memberikan hasil yang baik pula karena pupuk dapat terserap baik oleh tanaman, dengan demikian pemanfaatan unsur hara yang terkandung dalam pupuk dapat dimaksimalkan oleh tanaman dalam proses pertumbuhan tanaman itu sendiri. Kesalahan dalam cara pemberian pupuk akan mengurangi efesiensi dan efektifitas pupuk, sehingga akan timbul kerugian dari sisi waktu dan biaya serta manfaat pupuk yang kurang maksimal bagi tanaman.

Permasalahan dalam penelitian ini adalah belum diketahui pengaruh pemberian paket teknologi berupa pupuk hayati berupa FMA dan pupuk organik dari beberapa jenis pupuk kandang terhadap nilai produksi tanaman rumput Benggala sehingga perlu dilakukan penelitian yang bertujuan untuk mengetahui sejauh mana nilai pertumbuhan rumput Benggala yang diberi aplikasi FMA pada variasi pupuk kandang yang berbeda.

\section{Metode}

2.1 Waktu Dan Tempat Penelitian

Penelitin ini dilaksanakan pada lahan milik masyarakat di kelurahan Benpasi, Kecamatan Kota Kefamenanu, Kabupaten Timor Tengah Utara. Penelitian berlangsung selama 90 hari yang di mulai bulan Juni sampai Agustus 2015. Adapun penelitian terdiri dari dua priode dimana periode pertama berlangsung selama 45 hari sedangkan priode kedua berlangsung selama 45 hari.

\subsection{Rancangan Percobaan}

Rancangan yang digunakan dalam penelitian ini adalah Rancangan Acak Kelompok (RAK) yang terdiri dari empat perlakuan dan empat ulangan. Adapun perlakuan yang akan diuji adalah 1) $\mathrm{R}_{0}$ : Tanpa FMA dan pupuk kandang; 2) $\mathrm{R}_{1}$ : FMA $30 \mathrm{~g}+$ feses sapi $500 \mathrm{~g}$ per lubang tanam; 3 ) $\mathrm{R}_{2}$ : FMA 30 $\mathrm{g}+$ feses ayam $500 \mathrm{~g}$ per lubang tanam; 4) $\mathrm{R}_{3}$ : FMA $30 \mathrm{~g}+$ feses kambing 500 g per lubang tanam.

\subsection{Pelaksanaan Penelitian}

Penelitian diawali dengan pembersihan lahan yang dipakai dan dibuat dalam bentuk 16 buah bedengan yang terbagi dalam empat blok dengan ukuran tiap bedeng $2,7 \times 1,5 \mathrm{~m}$ dengan jarak antar bedeng $1 \mathrm{~m}$ dan jarak antar blok $1,5 \mathrm{~m}$ sehingga terdapat 16 satuan percobaan. Pupuk kandang yang digunakan terdiri atas 3 jenis meliputi pupuk kandang dari feses sapi, ayam dan kambing. Kebutuhan pupuk yang akan digunakan sebanyak $30 \mathrm{~kg}$ untuk setiap jenis pupuk, dimana nantinya akan diberikan 500 gram pupuk per lubang tanam sesuai dengan perlakuan tiap bedeng. Pupuk kandang yang akan digunakan diperoleh dari peternak sapi, ayam dan kambing yang berada diseputar Kota Kefamenanu.

Setelah bedeng dibuat selanjutnya dilakukan pembuatan lubang tanam. Pupuk kandang untuk setiap jenisnya ditempatkan pada lubang tanam yang telah dibuat, selanjutnya dibiarkan selama 3 hari agar mengurangi dampak dari kandungan amonia yang terkandung dalam pupuk. Pemberian pupuk 
kandang pada tiap bedeng sesuai dengan perlakuan dari hasil pengacakan yang dilakukan. Sebelum dilakukan penanaman pols rumput Benggala, terlebih dahulu diberikan FMA sebanyak $30 \mathrm{~g}$ pada lubang tanam. Selanjutnya tiap lubang tanam diisi 2 buah pols rumput Benggala lalu dipadatkan dengan tanah. Tiap pols rumput Benggala dipotong dengan ukuran $15 \mathrm{~cm}$ untuk menciptakan keseragaman. Penanaman dilakukan dengan jarak tanam $60 \times 60 \mathrm{~cm}$.

Kegiatan pemeliharaan yang dilakukan meliputi penyiraman dua kal sehari yaitu pada pagi dan sore hari, penggemburan dilakukan bila tanah pada bedengan sudah terlihat padat. Selanjutnya dilakukan penyiangan dalam rangka pengendalian terhadap gulma.

\subsection{Parameter Pengamatan}

\section{a. Tinggi Tanaman}

Tinggi tanaman diukur dari dari titik tumbuh hingga ujung daun yang paling tertinggi dengan menggunakan meter. Tinggi tanaman diukur satu minggu setelah trimming/pemangkasan kemudian dilakukan perhitungan rataan tinggi tanaman.

b. Lebar Daun

Lebar daun adalah bagian tumbuhan yang penting dalam fotosintesis dan pada umumnya tiap daun mempunyai jumlah yang berukuran besar dan kecil. Lebar daun diukur melintang dari sisi kiri ke sisi kanan daun rumput Benggala menggunakan mistar kemudian dilakukan perhitungan rataan lebar daun. c. Diameter Batang

Diameter batang dapat diukur dengan menggunakan jangka sorong dengan meletakan jangka sorong pada bagian batang rumput Benggala kemudian dilakukan perhitungan rataan diameter batang.

d. Jumlah Anakan

Jumlah anakan diukur dengan cara menghitung setiap anakan yang tumbuh setiap minggunya kemudian dilakukan perhitungan rataan jumlah anakan.

e. Berat Segar Tajuk

Berat segar tajuk diukur dengan cara penimbangan pada masa produksi pertama (45 HST) dan produksi kedua (90 HST).

f. Berat Kering Tajuk

Berat kering tajuk diukur dengan cara penimbangan pada masa produksi pertama (45 HST) dan produksi kedua (90 HST) dimana sebelumnya tajuk dikeringkan di dalam oven selama 48 jam pada suhu $70^{\circ} \mathrm{C}$.

g. Kadar Air Daun

Kadar air daun diukur dengan cara membandingkan selisih penurunan berat daun setelah dikeringkan dengan berat segar tajuk. Kadar air daun dihitung dengan rumus:

$$
\mathrm{KAD}=\frac{\mathrm{BST}-\mathrm{BKT}}{\mathrm{BST}} \times 100 \%
$$

$\begin{array}{cl}\text { Keterangan : } & \\ \text { KAD } & : \text { Kadar Air Daun }(\%) \\ \text { BST } & : \text { Berat Segar Tajuk (kg) } \\ \text { BKT } & : \text { Berat Kering Tajuk (kg) }\end{array}$

\subsection{Analisis Data}

Data yang diperoleh dalam penelitian ini dianalisa dengan analisa sidik ragam (ANOVA) berdasarkan Rancangan Acak Kelompok (RAK) dan dilanjutkan dengan uji jarak berganda Duncan untuk melihat perbedaan antar perlakuan sesuai petunjuk Steel dan Torrie (1995).

\section{Hasil dan Pembahasan}

Selama penelitian berlangsung nampak bahwa pertumbuhan tanaman berjalan dengan normal, hal ini ditandai dengan tidak terdapatnya tanaman yang mati pada setiap bedeng. Warna daun nampak segar dan cerah dan pertumbuhan anakan mulai terlihat pada minggu ke-3 dimana pada bagian rumpun tanaman nampak pertumbuhan tunas baru. Selain itu terlihat bahwa pertumbuhan tanaman rumput Benggala pada masa produksi pertama sedikit lebih lambat dibandingkan pada produksi ke-2. Hal ini dapat disebabkan karena pertumbuhan akar pada tanaman rumput Benggala pada fase awal masih berlangsung selain itu tanaman masih harus beradaptasi pada media tanam yang ada. Pada produksi ke dua nampak bahwa laju pertumbuhan tanaman rumput lebih cepat dibandingkan pada produksi pertama dimana dapat terlihat dari laju pertambahan tinggi tanaman dan jumlah anakan yang terjadi.

\subsection{Tinggi Tanaman}

Tinggi tanaman merupakan salah satu aspek dalam mengukur laju pertumbuhan tanaman. Potensi tinggi tanaman dapat dicapai secara maksimal apabila semua faktor yang mendukung pertumbuhan tanaman dapat terpenuhi. Menurut Noggle dan Fritz (1983) pertumbuhan dapat ditunjukkan dengan meningkatnya tinggi tanaman, panjang, lebar, dan luas daun, serta berat kering masing-masing organ yang meliputi akar, batang, daun dan buah; jumlah sel dan konsentrasi kandungan kimia tertentu, yaitu asam nukleat, nitrogen terlarut, lipid, karbohidrat dalam jaringan dan organ.

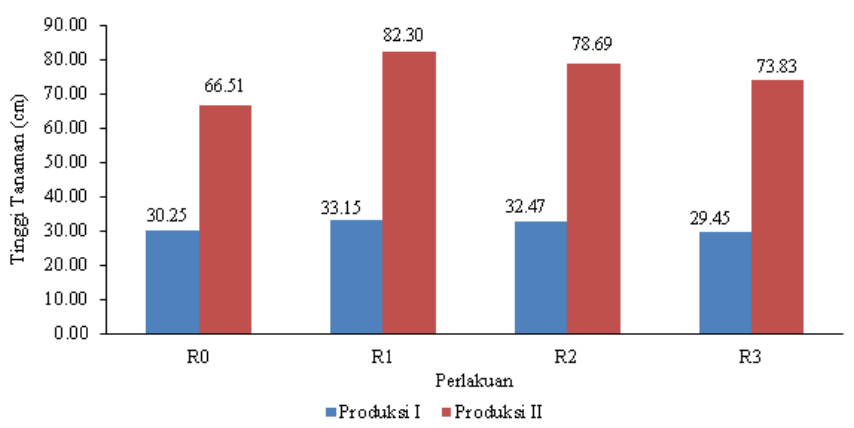

Gambar 1. Tinggi Tanaman Pada Produksi 1 dan produksi 2 (cm/bedeng/minggu)

Dari Gambar 1. dapat diketahui bahwa umumnya tinggi tanaman pada produksi ke-2 dapat mencapai nilai lebih baik dibandingkan pada produksi ke1. Hal ini menunjukkan terdapat perbedaan nilai tinggi tanaman rumput Benggala pada produksi ke-1 dan ke-2. Perbedaan tinggi tanaman dapat disebabkan karena pada produksi ke-2 tanaman sudah mengalami pertumbuhan akar dengan lengkap dan tanaman juga sudah dapat beradaptasi terhadap media tanam yang ada, selain itu juga dapat disebabkan karena pada pemangkasan akhir produksi ke-1 menyediakan karbohidrat yang cukup untuk pertumbuhan pada perode ke-2. Secara komulatif nilai ratan tinggi tanaman rumput benggala dapat dilihat pada Tabel 1 .

Tabel 1. Rataan Tinggi Tanaman (cm/bedeng/minggu)

\begin{tabular}{|c|c|c|c|c|c|}
\hline \multirow{2}{*}{ Perlakuan } & \multicolumn{4}{|c|}{ Kelompok } & \multirow{2}{*}{ Rataan } \\
\hline & I & II & III & IV & \\
\hline $\mathrm{R}_{0}$ & 44,95 & 45,63 & 50,38 & 52,56 & $48,38^{c}$ \\
\hline $\mathrm{R}_{1}$ & 52,60 & 57,65 & 58,55 & 62,10 & $57,72^{a}$ \\
\hline $\mathrm{R}_{2}$ & 59,62 & 51,86 & 56,14 & 54,68 & $55,58^{a b}$ \\
\hline $\mathrm{R}_{3}$ & 53,01 & 50,27 & 50,24 & 53,03 & $51,64^{\mathrm{ab}}$ \\
\hline Total & 210,18 & 205,41 & 215,31 & 222,36 & \\
\hline & $\begin{array}{l}\text { Angka } \\
\text { menjuka }\end{array}$ & $\begin{array}{l}\text { likuti } \\
\text { da san }\end{array}$ & $\begin{array}{l}\text { ip yan } \\
\text { a }(P<0 \text {, }\end{array}$ & eda 1 & \\
\hline
\end{tabular}

Dari Tabel 1. dapat diketahui bahwa nilai rataan tinggi tanaman rumput Benggala tertinggi ditunjukan pada perlakuan $\mathrm{R}_{1}(57,52)$ diikuti oleh perlakuan $\mathrm{R}_{2}(55,58) ; \mathrm{R}_{3}(51,64)$ dan $\mathrm{R}_{0}(48,38)$. Hal ini menunjukkan bahwa perlakuan kombinasi antara mikoriza dan pupuk feces sapi $\left(\mathrm{R}_{1}\right)$ memberikan nilai tinggi tanaman terbaik dibandingkan pada perlakuan lainnya. Namun secara umum dapat dikatakan bahwa variasi antara mikoriza dengan feces sapi, feces ayam maupun feces kambing memiliki nilai rataan terbaik pada tinggi tanaman dibandingkan yang tanpa diberikan mikoriza ataupun pupuk $\left(\mathrm{R}_{0}\right)$.

Hasil sidik ragam (Anova) menunjukkan nilai $\mathrm{F}$ hitung perlakuan $(7,20)$ lebih besar dibandingkan nilai $\mathrm{F}$ tabel sehingga dapat dikatakan bahwa perlakuan memberikan pengaruh sangat nyata $(\mathrm{P}<0,01)$, sedangakan pada $\mathrm{F}$ hitung kelompok $(1,37)$ menunjukkan tidak berbeda nyata $(P>0,01)$. Hal ini dikarenakan kotribusi nilai rataan tinggi tanaman pada kelompok relatif sama dibandingkan pada perlakuan, sehingga dapat dikatakan bahwa faktor-faktor yang dapat memberikan kontribusi error tidak nampak dalam penelitian ini.

Hasil uji lanjut duncan menunjukkan bahwa terdapat perbedaan yang sangat nyata antara setiap perlakuan baik antara $\mathrm{R}_{0}-\mathrm{R}_{1}, \mathrm{R}_{0}-\mathrm{R}_{2} ; \mathrm{R}_{0}-\mathrm{R}_{3} ; \mathrm{R}_{1}-\mathrm{R}_{2} ; \mathrm{R}_{1}$ $\mathrm{R}_{3}$ dan $\mathrm{R}_{2}-\mathrm{R}_{3}$. Hal ini menunjukkan bahwa setiap kombinasi perlakuan memberikan dampak yang berbeda terhadap nilai rataan tinggi tanaman. Hal ini dikarenakan bahwa setiap jenis feces memiliki kandungan bahan kimia organik yang berbeda-beda dan bahan organik sangat dibutukan oleh tanaman sebagai sumber nutrisi bagi tanaman selain itu dampak pemberian mikoriza mampu menyediakan mikrooganisme pada tanah sehingga proses penyerapan unsur hara dapat dilakukan secara maksimal untuk pertumbuhan tanaman. Menurut Setiadi (1990), tanaman yang bermikoriza akan tumbuh lebih baik dari tanaman tanpa mikoriza karena mikoriza secara efektif dapat meningkatkan penyerapan unsur hara makro, selain itu akar yang bermikoriza dapat menyerap unsur hara dalam bentuk terikat dan tersedia bagi tanaman. Disamping itu selain membentuk hifa internal mikoriza membentuk hifa eksternal yang berfungsi menyeap phospor dari dalam tanah. phospor yang telah diserap oleh hifa eksternal akan segera ditransfer ke tanaman induk.

\subsection{Lebar Daun}

Lebar daun merupakan salah satu ukuran yang dapat dipakai untuk mengetahui pertumbuhan tanaman rumput. Ukuran lebar daun pada tanaman rumput dari berbagai spesies tanaman yang ada sangat beragam. Ukuran lebar daun dari tanaman rumput Benggala sangat ditentukan oleh laju kecepatan tumbuh dari tanaman dan dipengaruhi oleh ketersediaan unsur hara, proses fotosintesis tanaman, sistim transportasi hara serta ketersediaan mikroorganisme tanah. 


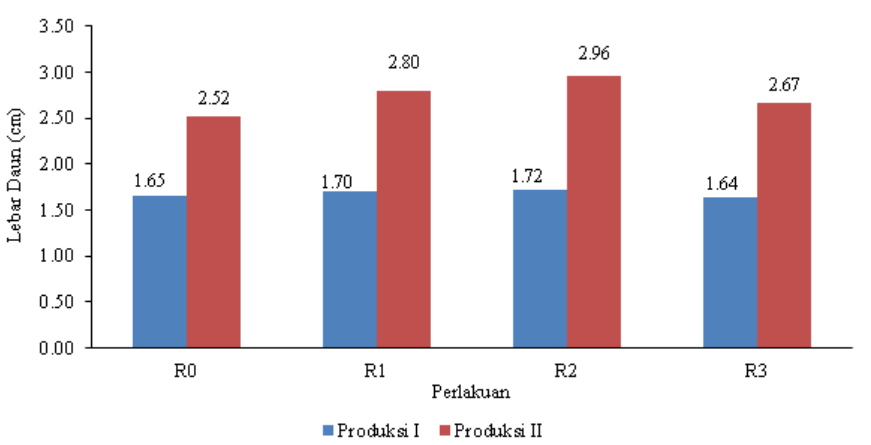

Gambar 2. Lebar Daun Pada Produksi 1 dan 2 (cm/bedeng/minggu)

Dari Gambar 2. diketahui bahwa umumnya lebar daun pada produksi ke-2 memiliki nilai rataan yang lebih tinggi dibandingkan pada produksi ke-1. Adanya perbedaan luas daun pada produksi ke-1 dan ke-2 dapat disebabkan karena kecepatan laju pertumbuhan pada produksi tanaman rumput Benggala yang berbeda. Pada masa produksi ke-1 masih terjadi pertumbuhan awal dari tanam sehingga perkembangan tanaman belum mencapai titik maksimal. Hal ini sesuai pendapat Novizan (2002) yang menyatakan bahwa pertumbuhan tanaman terdiri dari dua fase yaitu fase vegetatif dan fase generatif. Fase vegetatif terutama terjadi pada perkembangan akar, daun dan batang baru. Pada fase ini berhubungan dengan tiga proses penting yaitu 1) Pembelahan sel; 2) Perpanjangan sel dan; 3) Tahap pertama dari deferensiasi sel. Lebar daun secara komulatif dari hasil percobaan tanaman rumput Benggala dapat dilihat pada Tabel 2.

Tabel 2. Rataan Lebar Daun (cm/bedeng/minggu)

\begin{tabular}{|c|c|c|c|c|c|}
\hline \multirow[b]{2}{*}{ Perlakuan } & \multicolumn{4}{|c|}{ Kelompok } & \multirow[b]{2}{*}{ Rataan } \\
\hline & I & II & III & IV & \\
\hline $\mathrm{R}_{0}$ & 2,02 & 2,05 & 2,11 & 2,15 & $2,08^{\mathrm{c}}$ \\
\hline $\mathrm{R}_{1}$ & 2,17 & 2,22 & 2,27 & 2,33 & $2,25 \mathrm{ab}$ \\
\hline $\mathrm{R}_{2}$ & 2,47 & 2,27 & 2,29 & 2,32 & $2,34^{\mathrm{a}}$ \\
\hline $\mathrm{R}_{3}$ & 2,24 & 2,07 & 2,17 & 2,15 & $2,16^{\mathrm{bc}}$ \\
\hline Total & 8,90 & 8,61 & 8,84 & 8,95 & \\
\hline angan: & $\begin{array}{l}\text { Angka } \\
\text { menjul }\end{array}$ & $\mathrm{iku}$ & & & \\
\hline
\end{tabular}

Dari Tabel 2. diketahui bahwa nilai rataan lebar daun rumput Benggala tertinggi adalah pada perlakuan $R_{2}(2,34)$ diikuti perlakuan $R_{1}(2,25), R_{3}(2,16)$ dan yang terendah adalah pada perlakuan $\mathrm{R}_{0}(2,08)$. Hal ini dapat dikatakan bahwa kombinasi antara mikoriza dan pupuk kandang (faces sapi, ayam dan kambing) mampu memberikan kontribusi positif terhadap luas daun rumput Benggala.

Hasil sidik ragam (Anova) menunjukkan bahwa pada nilai $\mathrm{F}$ hitung perlakuan $(9,03)$ berbeda sangat nyata terhadap nilai $F$ tabel baik pada uji 0,05 maupun pada 0,01 . Sedangkan nilai $\mathrm{F}$ hitung kelompok tidak berbeda nyata terhadap nilai $\mathrm{F}$ tabel. Hal ini menunjukkan bahwa pengelompokan pada penelitian tidak memberikan dampak yang signifikan terhadap nilai rataan lebar daun rumput Benggala.

Hasil uji lanjut Duncan menunjukkan bahwa terdapat perbedaan yang sangat nyata $(\mathrm{P}<0,01)$ pada nilai rataan antara pasangan perlakuan. Adapun pasangan perlakuan yang dimaksud meliputi $\mathrm{R}_{0}-\mathrm{R}_{1} ; \mathrm{R}_{0}-\mathrm{R}_{2} ; \mathrm{R}_{0}-\mathrm{R}_{3} ; \mathrm{R}_{1}-\mathrm{R}_{2} ; \mathrm{R}_{1}-\mathrm{R}_{3}$ dan $R_{2}-R_{3}$. Hasil ini menunjukkan bahwa pemberian perlakuan mikoriza yang dikombinasikan dengan faces ayam $\left(\mathrm{R}_{2}\right)$ memberikan nilai rataan tertinggi terhadap lebar daun diikuti kombinasi mikoriza dan feces sapi $\left(\mathbf{R}_{1}\right)$ dan kombinasi mikoriza dengan feces kambing $\left(\mathrm{R}_{3}\right)$, sedangkan nilai rataan lebar daun terendah adalah pada perlakuan tanpa pemberian mikoriza dan feces $\left(\mathrm{R}_{0}\right)$. Sehingga dapat dikatakan bahwa perlakuan mikoriza yang dikombinasikan dengan feces (Ayam, Sapi dan Kambing) memberikan dampak yang signifikan terhadap nilai rataan lebar daun tanaman rumput Benggala. Hal ini sesuai pendapat Setyamidjaya (1986) bahwa kandungan unsur N, P, dan K pada setiap pupuk mempunyai peranan dalam meranggsang pertumbuhan vegetatif serta memacu pertumbuhan jaringan terutama pada diameter batang, tinggi tanaman, jumlah anakan dan lebar daun.

\subsection{Diameter Batang}

Diameter batang merupakan salah satu indikator tingkat pertumbuhan dari tanaman rumput Benggala. Dengan demikian semua faktor yang mempengaruhi pertumbuhan akar, batang dan daun mempengaruhi pula pada hasil produksi.

Dari Gambar 3. diketahui bahwa diameter batang pada produksi ke-2 memiliki nilai rataan yang lebih tinggi dibandingkan pada produksi ke-1. Adanya perbedaan diameter batang pada produksi ke-1 dan ke-2 dapat disebabkan karena kecepatan laju pertumbuhan pada produksi tanaman rumput Benggala yang berbeda. Pada masa produksi ke-1 masih terjadi pertumbuhan awal dari tanam sehingga perkembangan tanaman belum mencapai titik maksimal. Hal ini sesuai pendapat Novizan (2002) yang menyatakan bahwa pertumbuhan tanaman terdiri dari dua fase yaitu fase vegetatif dan fase generatif.

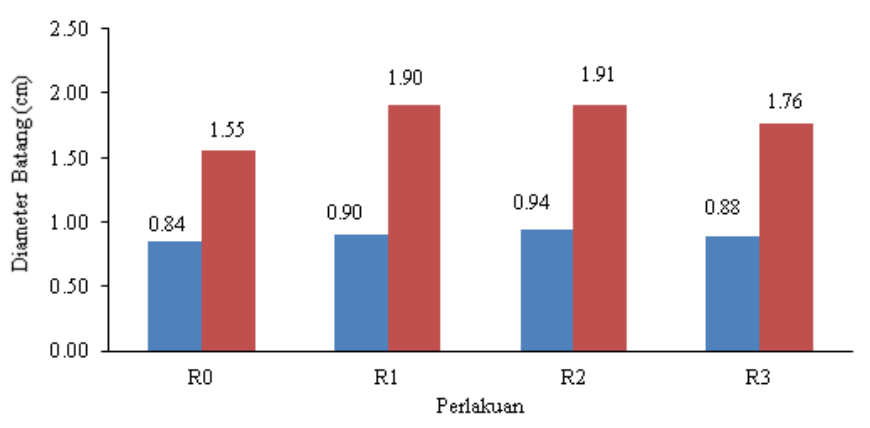

=Produksi I $=$ Produksi II

Gambar 3. Diameter Batang Pada Produksi 1 dan 2 (cm/bedeng/minggu)

Fase vegetatif terutama terjadi pada perkembangan akar, daun dan batang baru. Pada fase ini berhubungan dengan 3 proses penting yaitu 1) Pembelahan sel; 2) Perpanjangan sel dan; 3) Tahap pertama dari deferensiasi sel. Diameter batang secara komulatif dari hasil percobaan tanaman rumput Benggala dapat dilihat pada Tabel 3.

$\underline{\text { Tabel 3. Rataan Diameter Batang (cm/bedeng/minggu) }}$

\begin{tabular}{|c|c|c|c|c|c|}
\hline \multirow{2}{*}{ Perlakuan } & \multicolumn{4}{|c|}{ Kelompok } & \multirow{2}{*}{ Rataan } \\
\hline & $\mathrm{I}$ & II & III & IV & \\
\hline $\mathrm{R}_{0}$ & 1,12 & 1,17 & 1,23 & 1,28 & $1,20^{\mathrm{b}}$ \\
\hline $\mathrm{R}_{1}$ & 1,37 & 1,39 & 1,42 & 1,42 & $1,40^{\mathrm{a}}$ \\
\hline $\mathrm{R}_{2}$ & 1,53 & 1,34 & 1,45 & 1,38 & $1,43^{\mathrm{a}}$ \\
\hline $\mathrm{R}_{3}$ & 1,31 & 1,35 & 1,31 & 1,32 & $1,32^{\mathrm{a}}$ \\
\hline Total & 5,33 & 5,25 & 5,41 & 5,40 & \\
\hline 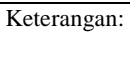 & $\begin{array}{l}\text { Angka } \\
\text { menjuk }\end{array}$ & $\begin{array}{l}\text { kuti } \\
\text { la sa }\end{array}$ & $\begin{array}{l}\text { rip }{ }^{\prime} \\
\text { ta }(P\end{array}$ & beda & \\
\hline
\end{tabular}

Dari Tabel 3. diketahui bahwa nilai rataan diameter batang rumput Benggala tertinggi adalah pada perlakuan $\mathrm{R}_{2}(1,43)$ diikuti perlakuan $\mathrm{R}_{1}(1,40)$, $\mathbf{R}_{3}(1,32)$ dan yang terendah adalah pada perlakuan $\mathbf{R}_{0}(1,20)$. Hal ini dapat dikatakan bahwa kombinasi antara mikoriza dan pupuk kandan (faces sapi, ayam dan kambing) mampu memberikan kontribusi positif terhadap diameter batang rumput benggala. Hasil sidik ragam (Anova) menunjukkan bahwa pada nilai $\mathrm{F}$ hitung perlakuan $(13,02)$ berbeda sangat nyata terhadap nilai $\mathrm{F}$ tabel baik pada uji 0,05 maupun pada 0,01 . Sedangkan nilai $F$ hitung kelompok tidak berbeda nyata terhadap nilai $\mathrm{F}$ tabel. Hal ini menunjukkan bahwa pengelompokan pada penelitian tidak memberikan dampak yang signifikan terhadap nilai rataan diameter batang rumput Benggala.

Hasil uji lanjut Duncan menunjukkan bahwa terdapat perbedaan yang sangat nyata $(\mathrm{P}<0,01)$ pada nilai rataan antara pasangan perlakuan. Adapun pasangan perlakuan yang dimaksud meliputi $\mathrm{R}_{0}-\mathrm{R}_{1} ; \mathrm{R}_{0}-\mathrm{R}_{2} ; \mathrm{R}_{0}-\mathrm{R}_{3} ; \mathrm{R}_{1}-\mathrm{R}_{2} ; \mathrm{R}_{1}-\mathrm{R}_{3}$ dan $R_{2}-R_{3}$. Hasil ini menunjukkan bahwa pemberian perlakuan mikoriza yang dikombinasikan dengan faces ayam $\left(\mathrm{R}_{2}\right)$ memberikan nilai rataan tertinggi terhadap diameter batang diikuti kombinasi mikoriza dan feces sapi $\left(\mathrm{R}_{1}\right)$ dan kombinasi mikoriza dengan feces kambing $\left(\mathrm{R}_{3}\right)$, sedangkan nilai rataan diameter batang terendah adalah pada perlakuan tanpa pemberian mikoriza dan feces $\left(R_{0}\right)$. Sehingga dapat dikatakan bahwa perlakuan mikoriza yang dikombinasikan dengan feces (Ayam, Sapi dan Kambing) memberikan dampak yang signifikan terhadap nilai rataan diameter batang tanaman rumput Benggala. Hal ini sesuai pendapat Setyamidjaya (1986) bahwa kandungan unsur $\mathrm{N}, \mathrm{P}$ dan $\mathrm{K}$ pada setiap pupuk mempunyai peranan dalam meranggsang pertumbuhan vegetatif serta memacu pertumbuhan jaringan terutama pada diameter batang, tinggi tanaman, jumlah anakan dan lebar daun.

\subsection{Jumlah Anakan}

Jumlah anakan merupakan penambahan populasi baru bagi setiap spesies tanaman. Penambahan populasi bagi setiap spesies tanamam berbeda-beda, ada yang dengan biji, buah dan anakan.

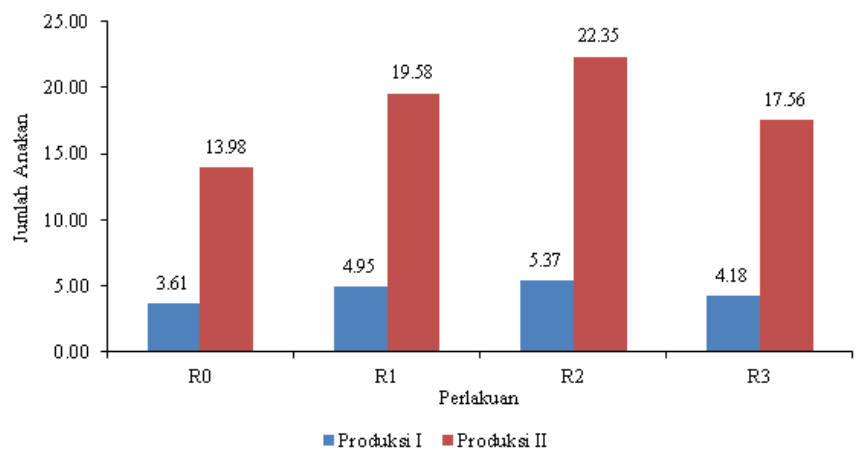

Gambar 4. Jumlah Anakan Pada Produksi 1 dan 2 (bedeng/minggu) 
Pada tanaman rumput benggala pertumbuhan anakan mulai terlihat pada minggu ke-3 dimana pada bagian rumpun tanaman nampak pertumbuhan tunas baru. Hal ini menandakan bahwa sistim perakaran tanaman suadah mulai beradaptasi dengan media tanam.

Dari Gambar 4. diketahui bahwa jumlah anakan pada produksi ke-2 memiliki nilai rataan yang lebih tinggi dibandingkan pada produksi ke-1. Adanya perbedaan jumlah anakan pada produksi ke-1 dan ke-2 dapat disebabkan karena kecepatan laju pertumbuhan pada produksi tanaman rumput Benggala yang berbeda. Pada masa produksi ke-1 masih terjadi proses penyesuaian sistim perakaran pada media tanam sehingga pertumbuhan rumput belum optimal. Hal ini sesuai pendapat Novizan (2002) yang menyatakan bahwa pertumbuhan tanaman terdiri dari dua fase yaitu fase vegetatif dan fase generatif. Fase vegetatif terutama terjadi pada perkembangan akar, daun dan batang baru. Pada fase ini berhubungan dengan 3 proses penting yaitu 1) Pembelahan sel; 2) Perpanjangan sel dan; 3) Tahap pertama dari deferensiasi sel. Jumlah anakan secara komulatif dari hasil percobaan tanaman rumput Benggala dapat dilihat pada Tabel 4.

Tabel 4. Rataan Jumlah Anakan (bedeng/minggu)

\begin{tabular}{|c|c|c|c|c|c|}
\hline \multirow{2}{*}{ Perlakuan } & \multicolumn{4}{|c|}{ Kelompok } & \multirow{2}{*}{ Rataan } \\
\hline & I & II & III & IV & \\
\hline $\mathrm{R}_{0}$ & 8,49 & 7,18 & 8,61 & 10,89 & $8,79^{\mathrm{c}}$ \\
\hline $\mathrm{R}_{1}$ & 11,11 & 10,85 & 12,08 & 15,02 & $12,27^{\mathrm{ab}}$ \\
\hline $\mathrm{R}_{2}$ & 15,13 & 11,66 & 14,13 & 14,52 & $13,86^{\mathrm{a}}$ \\
\hline $\mathrm{R}_{3}$ & 11,78 & 10,19 & 10,30 & 11,21 & $10,87^{\mathrm{b}}$ \\
\hline Total & 46,51 & 39,88 & 45,12 & 51,64 & \\
\hline Keterangan: & $\begin{array}{l}\text { Angka } \\
\text { menjuk }\end{array}$ & $\begin{array}{l}\text { diikuti } \\
\text { beda san }\end{array}$ & $\begin{array}{l}\text { rip } \\
\text { ta (P }\end{array}$ & rbeda & $\mathrm{m} \mathrm{r}$ \\
\hline
\end{tabular}

Dari Tabel 4. diketahui bahwa nilai rataan jumlah anakan rumput Benggala tertinggi adalah pada perlakuan $R_{2}(13,86)$ diikuti perlakuan $R_{1}(12,27), R_{3}$ $(10,87)$ dan yang terendah adalah pada perlakuan $R_{0}(8,79)$. Hal ini dapat dikatakan bahwa kombinasi antara mikoriza dan pupuk kandan (faces sapi, ayam dan kambing) mampu memberikan kontribusi positif terhadap jumlah anakan rumput Benggala. Hasil sidik ragam (Anova) menunjukan bahwa pada nilai $\mathrm{F}$ hitung perlakuan $(18,00)$ dan $\mathrm{F}$ hitung kelompok $(5,69)$ berbeda sangat nyata terhadap nilai $F$ tabel baik pada uji 0,05 maupun pada 0,01 . Hal ini menunjukkan bahwa perlakuan pada penelitian dapat memberikan dampak yang sangat signifikan terhadap nilai rataan jumlah anakan rumput Benggala.

Hasil uji lanjut Duncan menunjukkan bahwa terdapat perbedaan yang sangat nyata $(\mathrm{P}<0,01)$ pada nilai rataan antara pasangan perlakuan, adapun pasangan perlakuan yang dimaksud meliputi $\mathrm{R}_{0}-\mathrm{R}_{1} ; \mathrm{R}_{0}-\mathrm{R}_{2} ; \mathrm{R}_{0}-\mathrm{R}_{3} ; \mathrm{R}_{1}-\mathrm{R}_{2} ; \mathrm{R}_{1}-\mathrm{R}_{3}$ dan $R_{2}-R_{3}$. Hasil ini menunjukkan bahwa pemberian perlakuan mikoriza yang dikombinasikan dengan faces ayam $\left(\mathrm{R}_{2}\right)$ memberikan nilai rataan tertingg terhadap jumlah anakan diikuti kombinasi mikoriza dan feces sapi $\left(\mathrm{R}_{1}\right)$ dan kombinasi mikoriza dengan feces kambing $\left(\mathrm{R}_{3}\right)$, sedangkan nilai rataan jumlah anakan terendah adalah pada perlakuan tanpa pemberian mikoriza dan feces $\left(\mathrm{R}_{0}\right)$. Sehingga dapat dikatakan bahwa perlakuan mikoriza yang dikombinasikan dengan feces (Ayam, Sapi dan Kambing) memberikan dampak yang sangat signifikan terhadap nilai rataan jumlah anakan tanaman rumput Benggala. Hal ini sesuai pendapat Setyamidjaya (1986) bahwa kandungan unsur $\mathrm{N}$, P dan $\mathrm{K}$ pada setiap pupuk mempunyai peranan dalam meranggsang pertumbuhan vegetatif serta memacu pertumbuhan jaringan terutama pada diameter batang, tinggi tanaman, jumlah anakan dan lebar daun.

\subsection{Berat Segar Tajuk}

Berat segar tanaman merupakan salah satu aspek dalam mengukur laju produksi suatu tanaman. Potensi berat segar tanaman dapat dicapai secara maksimal apabila semua faktor yang mendukung pertumbuhan tanaman dapa terpenuhi. Berat basah atau berat segar suatu tanaman sangat mudah berubah, tergantung pada kadar air yang dikandungnya. Apabila jaringan tanaman mengering maka akan kehilangan berat segarnya. Secara komulatif nilai rataan berat segar rumput Benggala dari hasil penelitian dapat dilihat pada Tabel 5 .

Tabel 5. Rataan Berat Segar Tajuk (gram/bedeng)

\begin{tabular}{cccccc}
\hline \multirow{2}{*}{ Perlakuan } & \multicolumn{4}{c}{ Kelompok } & \multirow{2}{*}{ Rataan } \\
\cline { 2 - 5 } & $\mathrm{I}$ & $\mathrm{II}$ & $\mathrm{III}$ & $\mathrm{IV}$ & \\
\hline $\mathrm{R}_{0}$ & 1768,85 & 1048,55 & 1638,20 & 2685,05 & $1785,16^{\mathrm{b}}$ \\
$\mathrm{R}_{1}$ & 2073,35 & 1960,55 & 2501,25 & 4179,75 & $2678,73^{\mathrm{a}}$ \\
$\mathrm{R}_{2}$ & 2913,55 & 2186,60 & 2882,45 & 3025,80 & $2752,10^{\mathrm{a}}$ \\
$\mathrm{R}_{3}$ & 2121,55 & 1836,05 & 2143,05 & 2416,90 & $2129,39^{\mathrm{ab}}$ \\
\hline Total & 1768,85 & 1048,55 & 1638,20 & 2685,05 \\
\hline Keterangan: & \multicolumn{4}{c}{ Angka yang diikuti superskrip yang berbeda pada } & \\
& menjukan berbeda sangat nyata (P<0,01)
\end{tabular}

Dari Tabel 5. diketahui bahwa nilai rataan berat segar rumput benggala tertinggi ditunjukkan pada perlakuan $\mathrm{R}_{2}(2752,10)$ diikuti oleh perlakuan $\mathrm{R}_{1}$ (2678,73); $\mathrm{R}_{3}(2129,39)$ dan $\mathrm{R}_{0}(1785,16)$. Hal ini menunjukkan bahwa perlakuan kombinasi antara mikoriza dan pupuk feces sapi $\left(\mathrm{R}_{1}\right)$ memberikan nilai berat segar terbaik dibandingkan pada perlakuan lainnya. Namun secara umum dapat dikatakan bahwa variasi antara mikoriza dengan feces sapi, feces ayam maupun feces kambing memiliki nilai rataan terbaik pada berat segar dibandingkan yang tanpa diberikan mikoriza dan pupuk $\left(\mathrm{R}_{0}\right)$.
Hasil sidik ragam (Anova) menunjukan nilai $\mathrm{F}$ hitung perlakuan $(4,92)$ lebih besar dibandingkan nilai $\mathrm{F}$ tabel sehingga dapat dikatakan bahwa perlakuan memberikan pengaruh nyata $(\mathrm{P}<0,01)$, sedangkan pada $\mathrm{F}$ hitung kelompok $(6,94)$ menunjukan berbeda nyata $(\mathrm{P}<0,01)$. Hal ini dikarenakan kotribusi nilai rataan berat segar pada kelompok relatif beda dibandingkan pada perlakuan, sehingga dapat dikatakan bahwa faktor-faktor yang dapat memberikan kontribusi error tidak nampak dalam penelitian ini.

Hasil uji lanjut Duncan menunjukkan bahwa terdapat perbedaan yang sangat nyata antara setiap perlakuan baik antara $R_{0}-R_{1}, R_{0}-R_{2} ; R_{0}-R_{3} ; R_{1}-R_{2} ; R_{1}$ $\mathrm{R}_{3}$ dan $\mathrm{R}_{2}-\mathrm{R}_{3}$. Hal ini menunjukan bahwa setiap kombinasi perlakuan memberikan dampak yang berbeda terhadap nilai rataan berat segar. Hal ini dikarenakan bahwa setiap jenis feces memiliki kandungan bahan kimia organik yang berbeda-beda dan bahan organik sangat dibutukan oleh tanaman sebagai sumber nutrisi bagi tanaman selain itu dampak pemberian mikoriza mampu menyediakan mikrooganisme pada tanah sehingga proses penyerapan unsur hara dapat dilakukan secara maksimal untuk pertumbuhan tanaman.

\subsection{Berat Kering Tajuk}

Berat kering tanaman adalah berat suatu tanaman setelah melewati beberapa tahapan proses pengeringan. Berat kering tanaman menjadi salah satu parameter pertumbuhan tanaman yang mengidikasikan pola tanaman mengakumulasi produk dari proses fotosintesis, selain itu merupakan integrasi dengan faktor lingkungan lainnya. Secara komulatif nilai rataan berat kering rumput Benggala dari hasil penelitian dapat dilihat pada Tabel 6.

\begin{tabular}{|c|c|c|c|c|c|}
\hline \multirow[b]{2}{*}{ Perlakuan } & \multicolumn{4}{|c|}{ Kelompok } & \multirow{2}{*}{ Rataan } \\
\hline & I & II & III & IV & \\
\hline $\mathrm{R}_{0}$ & 225,00 & 191,00 & 413,85 & 475,25 & $326,28^{b}$ \\
\hline $\mathrm{R}_{1}$ & 370,35 & 382,00 & 542,00 & 959,40 & $563,44^{\mathrm{a}}$ \\
\hline $\mathrm{R}_{2}$ & 495,65 & 356,55 & 674,30 & 693,46 & $554,99^{\mathrm{a}}$ \\
\hline $\mathrm{R}_{3}$ & 391,45 & 341,20 & 524,25 & 517,25 & $443,54^{\mathrm{ab}}$ \\
\hline Total & 1482,45 & 1270,75 & 2154,40 & 2645,36 & \\
\hline Keterangan: & $\begin{array}{l}\text { Angka } \\
\text { menjuk }\end{array}$ & eda sar & $\begin{array}{l}\text { krip yan } \\
\text { ata }(P<0,0\end{array}$ & rbeda $p$ & om 1 \\
\hline
\end{tabular}

Dari Tabel 6. diketahui bahwa nilai rataan berat kering rumput Benggala tertinggi adalah pada perlakuan $R_{1}(563,44)$ diikuti perlakuan $R_{2}(554,99), R_{3}$ $(443,54)$ dan yang terendah adalah pada perlakuan $\mathrm{R}_{0}(326,28)$. Hal ini dapat dikatakan bahwa penerapan pemberian FMA pada variasi pupuk organik (faces sapi, ayam dan kambing) mampu memberikan pengaruh positif terhadap berat kering rumput Benggala.

Hasil sidik ragam (Anova) menunjukkan bahwa pada nilai $\mathrm{F}$ hitung perlakuan $(4,98)$ berbeda nyata terhadap nilai $\mathrm{F}$ tabel baik pada uji 0,05 maupun pada 0,01 . Sedangkan nilai $F$ hitung kelompok $(9,94)$ berbeda sangat nyata terhadap nilai $\mathrm{F}$ tabel. Hal ini menunjukkan bahwa pengelompokan pada penelitian memberikan dampak yang signifikan terhadap nilai rataan berat kering rumput Benggala.

Hasil uji lanjut Duncan menunjukkan bahwa terdapat perbedaan yang sangat nyata $(\mathrm{P}<0,01)$ pada nilai rataan antara pasangan perlakuan. Adapun pasangan perlakuan yang dimaksud meliputi $\mathrm{R}_{1}-\mathrm{R}_{0} ; \mathrm{R}_{2}-\mathrm{R}_{0} ; \mathrm{R}_{3}-\mathrm{R}_{0} ; \mathrm{R}_{1}-\mathrm{R}_{3}$ dan $\mathrm{R}_{2}-\mathrm{R}_{3}$. Hasil ini menunjukkan bahwa pemberian perlakuan mikoriza yang dikombinasikan dengan faces ayam $\left(\mathrm{R}_{1}\right)$ memberikan nilai rataan tertinggi terhadap berat kering diikuti kombinasi mikoriza dan feces sapi $\left(\mathrm{R}_{1}\right)$ dan kombinasi mikoriza dengan feces kambing $\left(\mathrm{R}_{3}\right)$, sedangkan nilai rataan berat kering terendah adalah pada perlakuan tanpa pemberian mikoriza dan feces $\left(\mathrm{R}_{0}\right)$. Sehingga dapat dikatakan bahwa perlakuan mikoriza yang dikombinasikan dengan feces (Ayam, Sapi dan Kambing) memberikan dampak yang signifikan terhadap nilai rataan berat kering tanaman rumput Benggala.

\subsection{Kadar Air Daun}

Kadar air adalah persentasi kandungan air suatu bahan yang dapat dinyatakan berdasarkan berat basah atau berdasarkan kadar air. Kadar air dalam bahan pangan sangat mempengaruhi kualitas dan daya simpan dari bahan pangan tersebut. Oleh karena itu, penentuan kadar air dari suatu bahan pangan sangat penting agar proses pengolahan maupun pendistribusian mendapat penanganan yang tepat. Secara komulatif nilai rataan kadar air rumput Benggala dari hasil penelitian dapat dilihat pada Tabel 7.

Tabel 7. Nilai Komulatif Kadar Air (\%)

\begin{tabular}{|c|c|c|c|c|c|}
\hline \multirow{2}{*}{ Perlakuan } & \multicolumn{4}{|c|}{ Kelompok } & \multirow{2}{*}{ Rataan } \\
\hline & I & II & III & IV & \\
\hline $\mathrm{R}_{0}$ & 80,23 & 76,11 & 75,57 & 79,68 & $77,90^{b}$ \\
\hline $\mathrm{R}_{1}$ & 79,99 & 80,16 & 78,65 & 79,17 & $79,49^{\mathrm{ab}}$ \\
\hline $\mathrm{R}_{2}$ & 83,91 & 80,89 & 78,91 & 78,80 & $80,63^{\text {a }}$ \\
\hline $\mathrm{R}_{3}$ & 79,90 & 80,92 & 76,99 & 77,83 & $78,91^{\mathrm{ab}}$ \\
\hline Total & 324,02 & 318,07 & 310,11 & 315,48 & \\
\hline eterangan & $\begin{array}{l}\text { Angka } \\
\text { menjuka }\end{array}$ & $\begin{array}{l}\text { kuti s } \\
\text { la sang }\end{array}$ & $\begin{array}{l}\text { ip yar } \\
\text { a }(\mathrm{P}<0\end{array}$ & eda $\mathrm{p}$ & $\mathrm{n}$ \\
\hline
\end{tabular}

Dari Tabel 7. diketahui bahwa nilai rataan kadar air rumput Benggala tertinggi adalah pada perlakuan $R_{2}(80,63)$ diikuti perlakuan $R_{1}(79,49), R_{3}$ $(78,91)$ dan yang terendah adalah pada perlakuan $R_{0}(77,90)$. Hal ini dapat 
dikatakan bahwa penerapan pemberian FMA pada variasi pupuk organik (faces sapi, ayam dan kambing) mampu memberikan pengaruh positif terhadap kadar air rumput Benggala.

Hasil sidik ragam (Anova) menunjukkan bahwa pada nilai $\mathrm{F}$ hitung perlakuan $(2,26)$ tidak berbeda nyata terhadap nilai $F$ tabel baik pada uji 0,05 dan 0,01 . Sedangkan nilai F Hitung kelompok $(3,36)$ berbeda nyata terhadap nilai $\mathrm{F}$ tabel 0,05. Hal ini menunjukkan bahwa pengelompokan pada penelitian memberikan dampak yang kecil nilai signifikan terhadap rataan kadar air rumput Benggala.

\section{Simpulan}

Dari hasil penelitian dapat disimpulkan bahwa terdapat perbedaan kecepatan tumbuh (tinggi tanaman, lebar daun, diameter batang dan jumlah anakan) pada tanaman rumput Benggala pada masa produksi I dan II, sedangkan secara komulatif dari hasil penelitian nampak bahwa pemberian Mikoriza $30 \mathrm{~g}+$ feces sapi $500 \mathrm{~g}$ memberikan kontribusi terbaik terhadap variabel tinggi tanaman $(57,72 \mathrm{~cm} /$ bedeng/minggu $)$ dan berat kering tajuk (563,44 gr/bedeng) sedangkan pada perlakuan Mikoriza $30 \mathrm{~g}+$ ayam $500 \mathrm{~g}$ memberikan kontribusi terbaik terhadap variabel lebar daun (2,34 $\mathrm{cm} /$ bedeng/minggu), diameter batang ( $1.43 \mathrm{~cm} /$ bedeng/minggu $)$, jumlah anakan (13.86 bedeng/minggu), berat segar tajuk $(2752,10 \mathrm{gr} / \mathrm{bedeng})$ dan kadar air daun $(80,63 \%)$.

\section{Pustaka}

Hatch, A. 1973. The Physical basic of Mycorrhizae in Pinus.

Noggle, G.R. dan G.J. Fritz. 1983 Introductory Plant Physiologi secound Edition. Prentice. Hall. Enc. Englewood Cliff, New Jersey 627p.

Novizan. 2004. Petunjuk Pemupukan yang Efektif. Agromedia Pustaka Utama, Jakarta.

Novizan. 2002. Petunjuk Pemupukan yang Efektif. Agromedia Pustaka Utama, Jakarta.

Owusu-Benoal, E. and A. Wild. 1980. Effects of Vesicular Arbuscular Mycorrhizae on the Rice of the Labile Poll of Soil Phospate. Plant and Soil. 54 : 233-242

Rohyadi, A. 1987. Infektifitas Jamur Micoriza Vesikular Arbuscular Di Tanah Podsolik Merah Kuning dan Pengaruhnya Terhadap Pertumbuhan Tanaman Jagung, Universitas Gadjahmada, Yogyakarta. Hal 6, 29.

Santoso. 1994. Komposisi Zat Gizi Buah Tomat. Penebar swadaya: Jakarta

Setiadi, Y. 1990. Proses Pembentukan VA Micoriza, Fakultas Kehutanan, Institut Pertanian Bogor. Bogor. Hal. 5 - 9

Setyamidjaya, D.J. 1986. Pupuk dan Pemupukan. CV. Simplex, Jakarta

Skerman, P. J. dan F. Riveror. 1990. Tropical Grasses. Food and Agricultural Organization of United Nations. Rome.

Steel, R.G.D, Torrie, J.H. 1995. Prinsip dan prosedur statistika: suatu pendekatan biometrik. Jakarta: Gramedia. 